FZMw Jg. 6 (2003) S. 66-81

\title{
Notes on Cage, Harmony, and Analysis ${ }^{1}$
}

\author{
by Rob Haskins
}

$$
-1-
$$

\begin{abstract}
'After I had been studying with him for two years, Schoenberg said, "In order to write music, you must have a feeling for harmony." I explained to him that I had no feeling for harmony. He then said that I would always encounter an obstacle, that it would be as though I came to a wall through which I could not pass. I said, "In that case I shall devote my life to beating my head against that wall."'2
\end{abstract}

Of all the well-known quotations by John Cage, this one is among his most provocative. It evokes the composer's indifference, even resistance, to harmony that forms such an important cornerstone in his mythos. But while the composer did in fact distance himself from harmonic systems early on, that distancing has helped to reinforce a tendency in Cage scholarship to minimize an engagement with the s o u n d s of his music in a detailed and critical way.

$$
-2-
$$

For instance, James Pritchett sketches, but falls short of explaining, Cage's peculiar approach to harmony in his discussion of the String Quartet in Four Parts (1950). Pritchett observes that the composer's approach allowed him "to divorce harmony from voice-leading, and thus produce a succession of harmonies that is truly freed from structural responsibility." $\mathrm{He}$ observes that the "fragmentation of the harmonic progression" is "distinctly Cagean" but avoids discussing exactly what is

\footnotetext{
Research for this essay was made possible in part by the Dena Epstein Award for Archival and Library Research in American Music of the Music Library Association, which support I gratefully acknowledge.

(Editorial note: This paper was given at Cage 2002: 90/10, a study day to discuss, perform and listen to John Cage's music. It took place on Saturday, 21 September 2002 at the Music Department of the University of Southampton. The day aimed to mark Cage's 90th birthday and the 10th anniversary of his death.)

2 John Cage, "Indeterminacy," in Silence: Lectures and Writings (Middletown: Wesleyan University Press, 1961), 261.
} 
fragmented. ${ }^{3}$ And indeed he never characterizes the pitch collection or gamut Cage used in the piece with regard to pitch class, intervallic content, position in pitch space, timbre, or indeed any other aspect that might afford a better understanding of it. Pritchett introduced another kind of analysis for the music that Cage composed after turning to chance. This type of analysis is limited to reconstructing, insofar as possible, the compositional process chosen for a piece. ${ }^{4}$

$$
-3-
$$

I'm sure Pritchett does not intend to ignore or trivialize the actual sounds of Cage's music. Still, it is possible to follow his manner of analytical commentary to an absurd end: to conclude that Cage was indifferent to the sounds in a 11 of his music - that any sounds would do just as well. In other words, one might decide that Cage's renunciation of harmony resulted from willful ignorance, not innovative thinking. For instance, Richard Taruskin cites another of the composer's remarks to develop this point of view, and, I think, oversimplifies the issue for the sake of rhetorical flourish:

'"The whole pitch aspect of music eludes me," he cheerfully told an interviewer. (You might as well say, "The whole lexical aspect of literature eludes me," or "The whole color aspect of painting eludes me.") Any success that such a musician might enjoy would devalue legitimacy. ${ }^{5}$

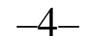

In a conversation in which Peter Gena remarks on Cage's "terrible ear for harmony," Morton Feldman appears precisely to foresee the possibility of reaching Taruskin's erroneous conclusion; to counter it, Feldman stresses that Cage had "impeccable ears," thus locating him within a traditional conception of the composer as an artist concerned with sound. ${ }^{6}$ While it's true that pitch plays little or no role in works like 4'33" and

James Pritchett, The Music of John Cage (Cambridge: Cambridge University Press, 1993), 50.

See, for instance, James Pritchett, "Understanding John Cage's Chance Music: An Analytical Approach," in John Cage at Seventy-Five, ed. Richard Fleming and William Duckworth (Lewisburg, PA: Bucknell University Press, 1989), 249-261 and The Music of John Cage, 78-88.

5 Richard Taruskin, "No Ear for Music: The Scary Purity of John Cage," The New Republic Issue 4,078 (March 15, 1993): 27.

6 See Morton Feldman and Peter Gena, "H. C. E. (Here Comes Everybody): Morton Feldman in Conversation with Peter Gena," in A John Cage Reader: in Celebration of his $70^{\text {th }}$ Birthday, compiled and edited by Peter Gena and Jonathan Brent, with supplementary editing by Don Gillespie (New York: C. F. Peters, 1982), 54-55. 
other pieces that characterize what I want to call the "non-work" extreme in Cage's career, these works do not form the bulk of his oeuvre. ${ }^{7}$

I would like to explore this complicated question by assuming a simple hypothesis: that Cage was, indeed, very sensitive to sound and that we can serve his music well by examining these sounds more critically. I do not intend to suggest that pitch structures should be reclaimed as the central element in Cage's music; the extreme variety of his output makes such a claim untenable. Nevertheless, I want to explore ways in which pitches contribute to o u r ow ex perie n c e of the music. I see my inquiry as one that extends an already rich discourse.

$$
-6-
$$

Before I can undertake this project, however, I believe we need to understand better the way in which Cage viewed harmony and analysis by examining his early development as a composer and the evidence of his mature writings and published interviews. What is more, I believe that revisiting his remarks about harmony and analysis will help us to elucidate some of what is at stake in our own responses to his later aesthetic of chance and indeterminacy.

$$
-7-
$$

To some degree, we can reconstruct Cage's earliest learning experiences-his distortion of Ebenezer Prout's harmony exercises; his suggestion that Alfredo Casella's survey of cadences in Western Music proves the cadence underwent a slow disintegration throughout its history; and of course his studies with Weiss and Schoenberg, which led him eventually to adopt the organizational principle of structural rhythm. I have traced the reception of "harmony" in Cage's published texts in mostly chronological fashion. While an account of this lengthy reception history is beyond the scope of this essay, I will mention a few points that are relevant. ${ }^{8}$

\footnotetext{
7 For more on this point, see "Toward a Critical Description of John Cage's Compositions" (paper presented at the American Musicological Society St. Lawrence Chapter Meeting, School of Performing Arts, SUNY Geneseo, Geneseo, New York, April 2002)—abstract available online at http://robhaskins.net/writings/AMS2002abs.htm.

$8 \quad$ For briefer treatments of the same topic, see James Tenney, "John Cage and the Theory of Harmony," in Writings about John Cage, ed. Richard Kostelanetz (Ann Arbor: University of Michigan Press, 1994), 140-150 and Eric de Visscher, "John Cage and the Idea of Harmony," Musicworks 52 (Spring 1992): 50-56. My own reception history appears in "'An Anarchic Society of Sounds': The Number Pieces of John Cage" (Ph.D. diss., Eastman School of Music, University of Rochester (in progress), 121-167.
} 
First, when Cage uses the word "harmony," he almost always means tonal harmony. In 1942, for example, he observes that the composer who writes for percussion instruments deals "with material that does not fit into the orthodox scales and harmonies." ${ }^{9}$ When he does mention the dominant musical systems of his time-twelve-tone music and neoclassicism, he dismisses both. Cage calls twelve-tone music a "method," thus (in his definition) only a means of controlling note-to-note succession and therefore not a structure, which he defined as "divisibility into successive parts from phrases to long sections." 10 By contrast, neoclassic composers only look anew at tonal harmony to fulfill the structural needs of their music; their system remains triadic and assumes some sort of pitch centricity. In this sense, then, neoclassic composers refuse to recognize "the contemporary need for another structure" - that is, a structure that can accommodate all sounds. ${ }^{11}$ In other writings of the 1940s, Cage castigates harmony for its effect. He asserts, for instance, that the emphasis on harmony in Messiaen accounts for his occasional bad taste; further, since harmony has "the ability to enlarge sound and thus to impress an audience, it has become in our time the tool of Western commercialism."12

$$
-9-
$$

After Cage's turn to chance in the 1950s, his remarks on harmony help to explain the change in his aesthetic. In the Lecture on Nothing, for instance, he tells us that harmonic systems erect barriers between the sounds of a musical composition and their audition: in tonal music, one must first understand the expected syntax that harmony provides before one fully appreciates a particular sequence of chords. Likewise, Schoenbergian atonality imposes restrictions by eliminating any intervals (such as octaves and triadic harmonies) that might suggest tonality. Both cases, in Cage's view, are predicated upon unbreakable rules guaranteed to exclude; by contrast, he wants a music in which a $\mathrm{n} y$ sound is equally welcome. ${ }^{13}$

Cage, "For More New Sounds" (originally pub. 1942), in John Cage: An Anthology, ed. Richard Kostelanetz (New York: Praeger, 1970; reprint, New York: Da Capo, 1991), 66 (my emphasis).

Cage, "Forerunners of Modern Music" (originally pub. 1949), in Silence, 62.

Cage, "Forerunners," 63.

Cage, "The East in the West" (originally pub. 1946) in John Cage: Writer, ed. Richard Kostelanetz (New York: Limelight Editions, 1993), 24-25. See Cage, "Lecture on Nothing" (1950) in Silence, 116. 
In 1957, Cage invokes a concept called "fusion," which signifies the way in which the elements of tonal harmony are blended together so that they acquire meaning only by combination with each other and in relation to other combinations of pitches. ${ }^{14}$ To prevent this from happening in contemporary music, Cage advises separating instruments as widely as possible. Thus, he redefines "fusion" more generally, as a moment in time in which separate sounds, each sufficient in themselves, momentarily combine to create larger connections. In Cage's ideal new music, this kind of fusion changes with respect to the position of a listener in the audience-even, perhaps, with respect to the listener's momentary state of mind, which has been brought about by openness to all possibilities. Omitting the few, somewhat unusual, remarks on harmony that we can find over the next several decades, I come to his final years. Here, Cage forged a reconciliation with harmony, which he now defined as "several sounds... being noticed at the same time."15

$$
-11-
$$

I would now like to turn to Cage's remarks on audition, which I believe point the way toward a helpful method to engage with the sounds of his music. The first important idea comes from his preference of what he calls "continuity" over "structure" in his writings of the 1950s, as in this quotation from the Lecture on Something: "Nocontinuity simply means accepting that continuity that happens. Continuity means the opposite: making that particular continuity that excludes all others."16

$$
-12-
$$

In the context of this lecture, "making a continuity" surely refers to a composer's intentional act of creating a structure that he wants the listener to hear. Such a continuity excludes other possibilities because it originates in the composer's mind. Immediately we detect a similarity between the rigidity of intentional continuity and Cage's inflexible, rule-bound conception of harmony that I mentioned earlier. But the absence of an intentional continuity does not necessarily mean that continuities cease to exist

See Cage, "Experimental Music" (originally pub. 1957) in Silence, 12 and "Composition as Process: II: Indeterminacy" (originally pub. 1958), in Silence, 39.

15 Cage and Joan Retallack, Musicage: Cage Muses on Words, Art, Music. John Cage in Conversation with Joan Retallack, ed. Joan Retallack (Middletown: Wesleyan University Press, 1996), 108.

16 Cage, "Lecture on Something" (written 1951, originally pub. 1961), in Silence, 132. The term "nocontinuity," Cage explains, originates with Feldman. 
altogether. Cage tells us that Morton Feldman picks and chooses as he does because he feels no particular obligation to make one continuity over another. ${ }^{17}$ The variety of his choices—as Cage sees it—can extend to our listening as well. The broad possibilities of "new" picking and choosing point toward another way of apprehension, one in which the listener attends to sounds and makes for himself a continuity from them which does not $\mathrm{d}$ e f i n e the piece of music, but rather evokes one of many shifting possibilities.

$$
-13-
$$

Another remark, given without a citation in Michael Nyman's 1974 book Experimental Music, offers the most powerful evidence I have yet found for this alternate way of attending to "relationships" in Cage's music:

'I would assume that relations would exist between sounds as they would exist between people and these relationships are more complex than any I would be able to prescribe. So by simply dropping that responsibility of making relationships I don't lose the relationship. I keep the situation in what you might call a natural complexity that can be observed in one way or another. ${ }^{18}$

$$
-14-
$$

Of course, in an environment as open as this one, the act of communicating what one has observed remains an option, not an obligation. And accordingly we have Cage statements that make clear the option of non-communication (or perhaps what we might think of as "no-communication"). Here, for instance, a quotation from 1961:

'There are temptations for us to stop what we're doing and make a connection that will be overwhelming. Well, perhaps it is. I haven't seen yet. I've seen some. But I'm losing my ability to make connections because the ones I do make so belittle the natural complexity. ${ }^{19}$

17 Cage, "Lecture on Something" (ca. 1951-1952) in Silence, 132-133.

18 Cage quoted in Michael Nyman, Experimental Music: Cage and Beyond (New York: Schirmer Books, 1974; second ed., New York and Cambridge: Cambridge University Press, 1999), 25 (date of original unknown; my emphasis). 
Most important, perhaps, Cage seems to warn us that making relationships can be counterproductive because it tempts us to stop listening once we have found the relationship, the "overwhelming" connection. As we know, some writers have suggested that avoiding relationships altogether constitutes the "appropriate" response to Cage's music. Any statements to the contrary-like the others I've mentioned-are simply contradiction or perhaps Zen paradox. But in choosing this path we oversimplify the richness of Cage's rhetoric_-what seems at first a contradiction emerges, in fact, as the opening of every door. We can communicate what we hear, or we can remain silent. If we remain silent, we might experience the essential, ecstatic mystery of "nounderstanding"; by sharing our experience, we are "keeping the doors open, by some fluent disclosure." ${ }^{20}$ As a result, we gain a potentially richer understanding of Cage's achievement in its totality.

$$
-16-
$$

With the foregoing in mind, I would like to conclude this essay with a few observations on two works, the Sonata XII from Sonatas and Interludes for Prepared Piano (194648) and $T w o^{2}$ (1989). Although the earlier piece requires one of the most elaborate preparation schemes in any of Cage's music, those for Sonata XII nonetheless allow the original pitches ( $B S$ and $F \# s$ ) to remain clearly audible; in addition, a substantially greater number of unprepared pitches appear. A list of prepared and unprepared pitch material in this sonata appears in Figure 1.

Cage, “Where Are We Going?", in Silence, 256-257. Compare Cage's contradiction to this remark from the "Diary: How To Improve the World (You Will Only Make Matters Worse) Continued 1970-71,' (1971), in M: Writings, '67-'72 (Middletown: Wesleyan University Press, 1973), 99: "Asked what he thought of first lecture, Suzuki said, 'Excellent, but in Zen most important thing's life.' Asked next day what he thought of second lecture, Suzuki said, 'Excellent, but in Zen most important thing's death.' 'How can you say life one day and death the next?' 'In Zen there's not much difference between the two."” 
Figure 1.

Pitch material in Sonata 12 from Sonatas and Interludes.

\begin{tabular}{|l|l|l|l|l|l|l|l|l|l|l|}
\hline & $\mathrm{C}^{7}$ & $\mathrm{D}^{7}$ & & $\mathrm{E}^{7}$ & & $\mathrm{~F}^{7}$ & $\mathrm{G}^{7}$ & & $\mathrm{~A}^{7}$ & $\mathrm{~B}^{7}$ \\
\hline $\mathrm{C}^{6}$ & $\mathrm{C}^{6}$ & $\mathrm{D}^{6}$ & $\mathrm{D}^{6}$ & $\mathrm{E}^{6}$ & $\mathrm{~F}^{6}$ & $\mathrm{~F} \#^{6}$ & $\mathrm{G}^{6}$ & & $\mathrm{~A}^{6}$ & $\mathrm{~B}^{6}$ \\
\hline $\mathrm{C}^{5}$ & $\mathrm{C} \#^{5}$ & $\mathrm{D}^{5}$ & $\mathrm{D} \#^{5}$ & $\mathrm{E}^{5}$ & & $\mathrm{~F} \#^{5}$ & $\mathrm{G}^{5}$ & $\mathrm{G} \#^{5}$ & $\mathrm{~A}^{5}$ & $\mathrm{~B}^{5}$ \\
\hline & $\mathrm{C} \#^{4}$ & $\mathrm{D}^{4}$ & & $\mathrm{E}^{4}$ & & $\mathrm{~F}^{4}$ & $\mathrm{G}^{4}$ & $\mathrm{G} \#^{4}$ & $\mathrm{~A}^{4}$ & $\mathrm{~B}^{4}$ \\
\hline & & $\mathrm{D}^{3}$ & & & & $\mathrm{~F}^{3}$ & $\mathrm{G}^{3}$ & & $\mathrm{~A}^{3}$ & $\mathrm{~B}^{3}$ \\
\hline & $\mathrm{C} \#^{2}$ & $\mathrm{D}^{2}$ & & $\mathrm{E}^{2}$ & & $\mathrm{~F}^{2}$ & $\mathrm{G}^{2}$ & & $\mathrm{~A}^{2}$ & $\mathrm{~B}^{2}$ \\
\hline & $\mathrm{C} \#^{1}$ & $\mathrm{D}^{1}$ & & $\mathrm{E}^{1}$ & & $\mathrm{~F} \#^{1}$ & $\mathrm{G}^{1}$ & & $\mathrm{~A}^{1}$ & $\mathrm{~B}^{1}$ \\
\hline
\end{tabular}

Grey $=$ prepared $\quad$ White $=$ unprepared

$-17-$

As shown, the unprepared notes include three instances of $B$ and six of $F \#$, which reinforce a sense of tonal centricity around $B$. To be sure, $B$ 's primacy is odd since it is "colored" by the prepared piano tones of less definite pitch. Three brief excerpts from the sonata demonstrate this singular pitch centricity. In mm. 12-15 (Figure 2), one hears a pentatonic collection $(B, D, E, F \#, A)$; the linear progression of the uppermost voice clearly asserts $B$ as the central pitch.

Figure 2:

Sonata XII from Sonatas and Interludes, mm. $12-15 .^{21}$

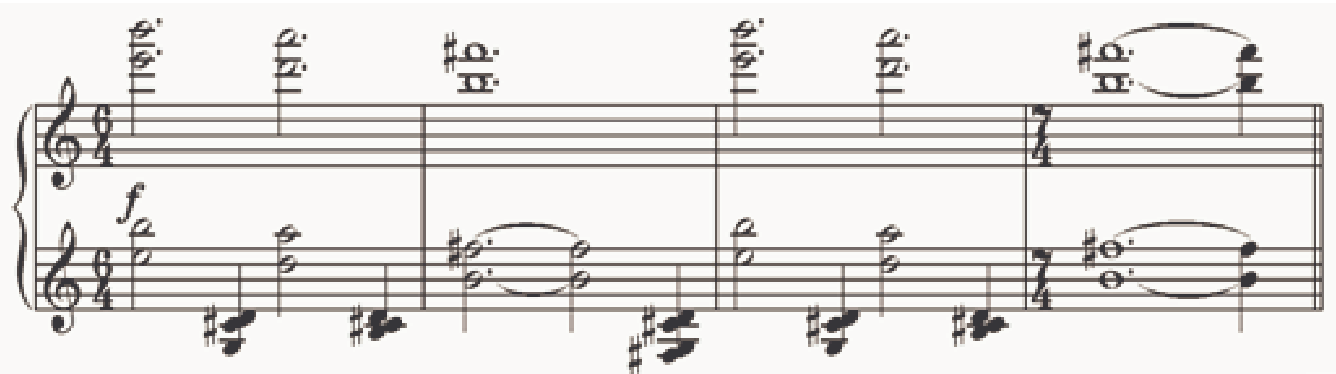

Copyright () 1960 by Henmar Press, Inc. Reproduced by kind permission; all rights reserved.

21 All musical examples (C) by Henmar Press, New York. Published with permission from C. F. Peters, New York. 


$$
-18-
$$

In a later passage (Figure 3), a descending line of first-inversion bass triads are all on unprepared pitches with the single exception of the lowest $D ;^{22}$ the line begins and ends with an A-major triad, further suggesting (as VII) the initial center of $B$ and (as V) a second pitch, $D$, that begins to assert itself as central during the second half of the sonata.

Figure 3:

Sonata XII from Sonatas and interludes, mm. 24-31.
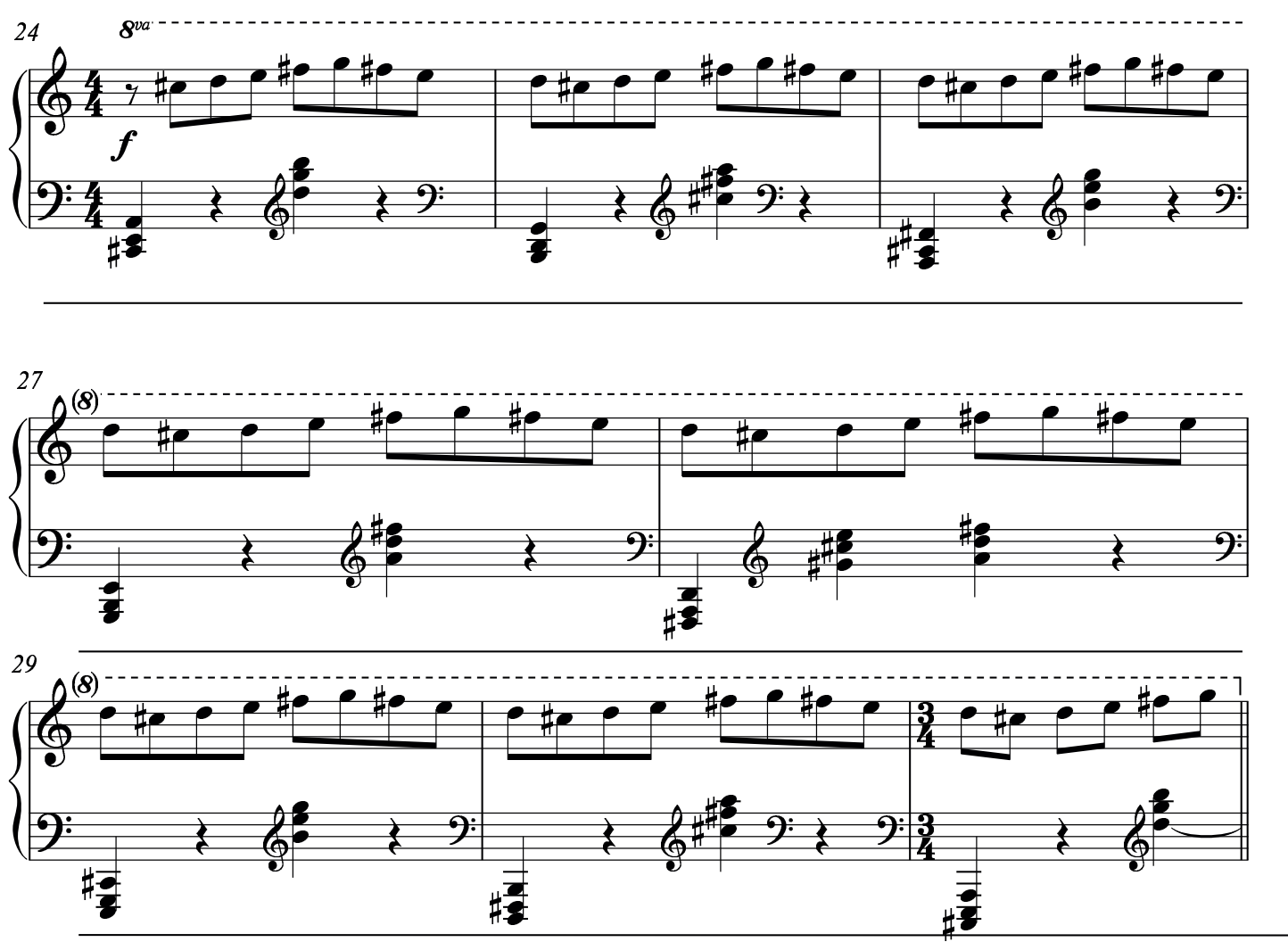

Copyright $\odot 1960$ by Henmar Press, Inc. Reproduced by kind permission; all rights reserved.

The series of second-inversion triads in the right hand includes prepared notes and it is therefore more difficult to hear these sonorities as conventional triads. 
The final cadential gesture (Figure 4), confirms this secondary pitch as the point of arrival (including another unprepared $D){ }^{23}$

Figure 4:

Sonata XII from Sonatas and Interludes, mm. 46-48.

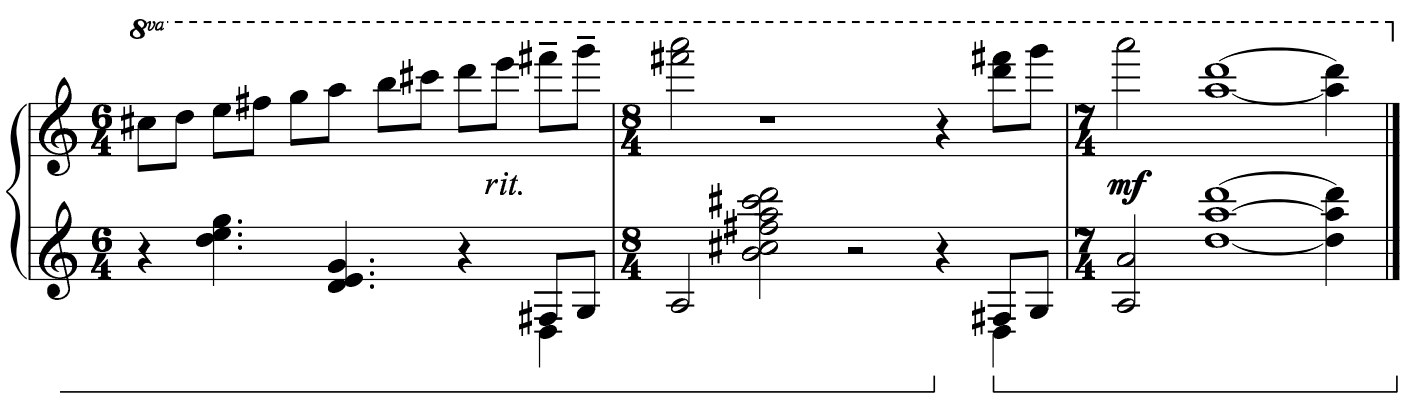

Copyright $\odot 1960$ by Henmar Press, Inc. Reproduced by kind permission; all rights reserved.

$-19-$

Now I will discuss $T w o^{2}$. As we all know, analysis of a Cage chance composition must take into account "the questions that are asked"; that is, the discovery, where this is possible, of the compositional process that Cage used. ${ }^{24}$ For the purposes of this essay, I can only mention one aspect in Cage's compositional process. He begins with an initial supply of separate sonorities for the two pianists, from single notes to pentachords; these are often repeated within a single section or even at wider distances, as I show in Figure 5. In addition to this recurrence, which is in any case a kind of low-level correspondence resulting from Cage's compositional method, we can discover additional relationships, other clearly audible markers that allow listeners to discover a thread in the fabric of continuity in the work-the observation of miracle, as Cage might put it. ${ }^{25}$

\footnotetext{
23 David W. Bernstein briefly notes tonal centricity in this and other movements of Sonatas and Interludes; see "Music I: to the Late 1940s," in The Cambridge Companion to John Cage, ed. David Nicholls (Cambridge: Cambridge University Press, 2002), 84.

24 See, for instance, Cage's use of this phrase in Conversing With Cage, ed. Richard Kostelanetz (New York: Limelight Editions, 1994), 12. The excerpt was originally printed in Robin White, "An Interview with John Cage at Crown Point Press," View 1, no. 1 (April 1978): 5. Cage, "Where Are We Going? And What Are We Doing," in Silence, 220-221.
} 
Figure 5:

$T w o^{2}$, Sections 1 and 8.
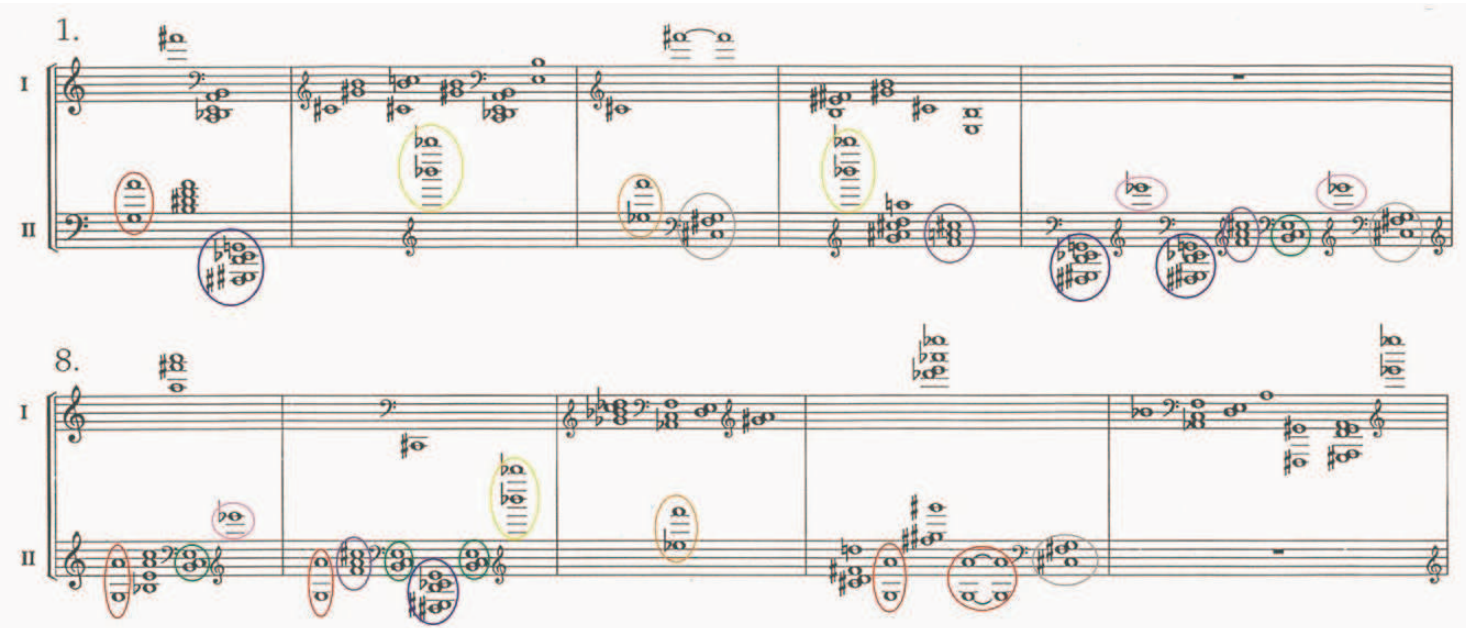

Copyright (C) 1989 by Henmar Press, Inc. Reproduced by kind permission; all rights reserved.

$-20$

In Figure 6, we see two tetrachords realized similarly in pitch space. The upper two tones are identical in both, with the lower two only a half-step apart. In performance, the order of tones within a measure must be observed by each pianist but the relation of one pianist to the other is completely free. Thus, the two tetrachords need not occur in the order shown on the page. The effect of harmonic connection-equally arresting no matter which tetrachord occurs first-is strongest when the tetrachords are temporally close to each other; even when they are not, however, their proximity in pitch space helps reinforce the association. Such an effect takes place often in the piece; with repeated hearings, it strikes me as a motif of the work.

Figure 6:

$T w o^{2}$, Section 5.

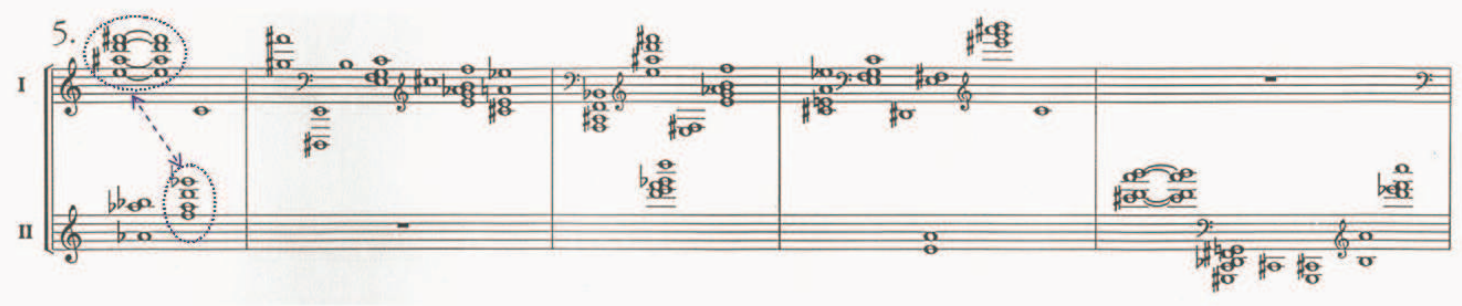

Copyright (C 1989 by Henmar Press, Inc. Reproduced by kind permission; all rights reserved. 
A second effect suggests a kind of tonal focusing - a moment in which the chance operations permit a slow saturation of a section or group of contiguous sections with a certain pitch. See Figure 7, in which I have circled instances of the pitch A. From that point, the pitch appears more frequently in both parts, here as a single note, elsewhere as part of a Cagean aggregate. ${ }^{26}$ Two other factors heighten the sensation of tonal focusing: the way that the sonorities become less dense as the passage proceeds, and the frequent occurrences of the $A$ in successively lower registers.

Figure 7:

Two ${ }^{2}$, Sections 10-12
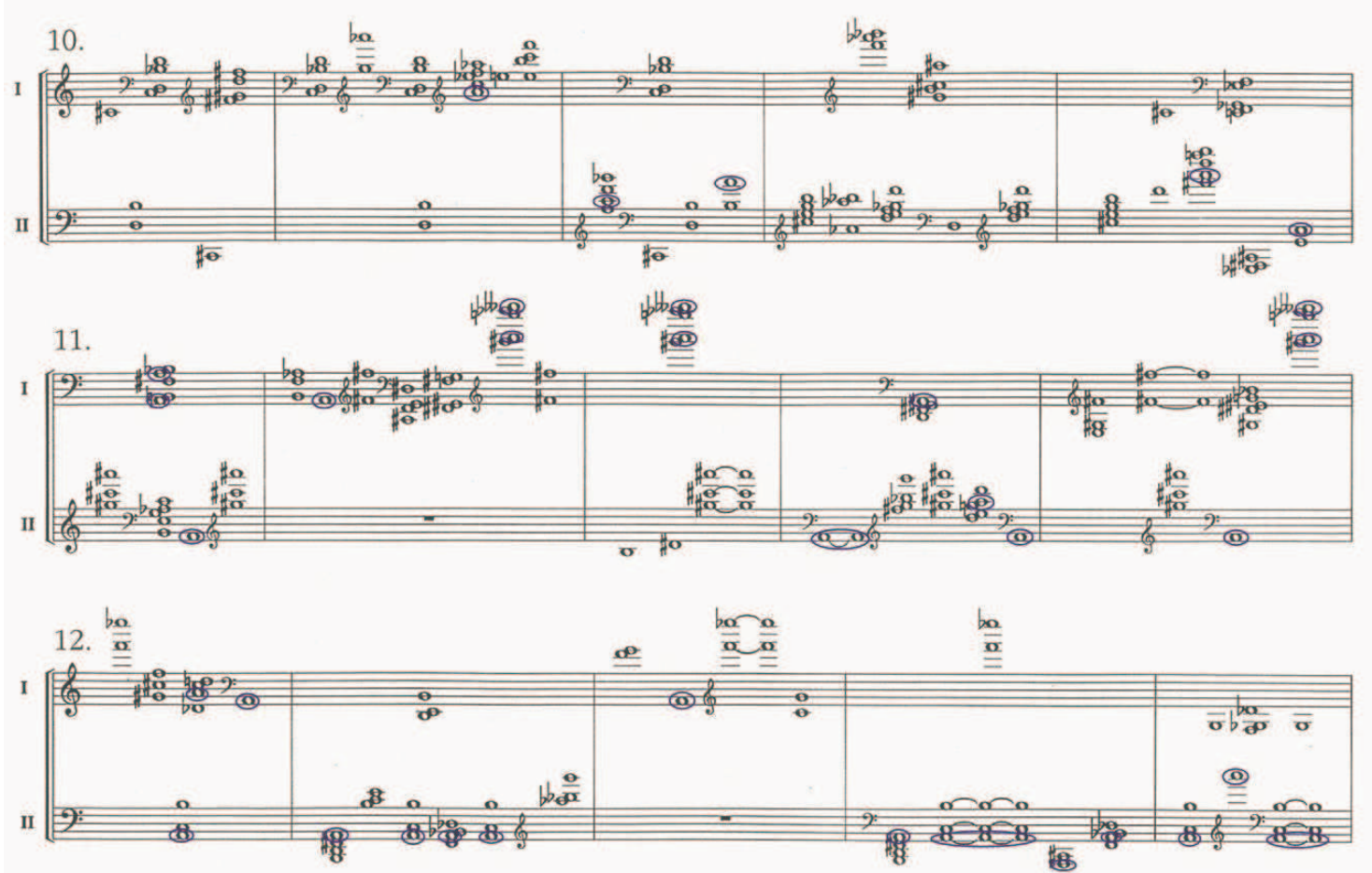

Copyright @ 1989 by Henmar Press, Inc. Reproduced by kind permission; all rights reserved.

26 By invoking the term "Cagean aggregate," I call attention to the important distinction between his definition of "aggregate" (a collection of simultaneous pitches, with or without pitch duplication) and the familiar definition (in post-tonal theory) of "aggregate" as the statement of all twelve tones of the chromatic collection. 
The history of Cage's attitude toward harmony and listening is one that suggests ambiguity and heterogeneity. Taken in toto, however, it seems evident that these remarks-like the wide variety of Cage's music_-suggest many possibilities for how we might meaningfully engage with that music. One of those possibilities, surely, is analysis of its pitch or timbral content - an act whose aim should not be to convince us of a single, overriding plan, nor to bestow the problematic appellation of "masterpiece" upon a composition. Rather, this sort of analysis occasions a reasoned, individual activity that represents one of the varying accounts of the "continuity" in Cage's music_-only one because chance and indeterminacy bring about a continuity which can never be wholly described or explained. This kind of approach-far from violating the spirit of Cage's aesthetics-fulfills his wish for a discourse "more affluent, each remark unfolding unsuspected ideas and turns of thought." 27 As such, it points the way to a new phase of Cage scholarship, largely untapped, that holds promise.

27 Cage, "Rhythm, etc.," in A Year from Monday: New Lectures and Writings (Middletown: Wesleyan University Press, 1967), 131. 


\section{References}

Bernstein, David. "Music I: to the Late 1940s." In The Cambridge Companion to John Cage, ed. David Nicholls, 63-84. Cambridge: Cambridge University Press, 2002.

Cage, John. "Forerunners of Modern Music." In Silence: Lectures and Writings, 62-66. Middletown: Wesleyan University Press, 1961.

—. "Experimental Music." In Silence: Lectures and Writings, 7-12. Middletown: Wesleyan University Press, 1961.

—. "Composition as Process: II: Indeterminacy." In Silence: Lectures and Writings, 35-40. Middletown: Wesleyan University Press, 1961.

- "Lecture on Something." In Silence: Lectures and Writings, 128-145. Middletown: Wesleyan University Press, 1961.

— . "Where Are We Going? And What Are We Doing?" In Silence: Lectures and Writings, 194-259. Middletown: Wesleyan University Press, 1961.

—. "Indeterminacy." In Silence: Lectures and Writings, 260-273. Middletown: Wesleyan University Press, 1961.

_. "Rhythm etc." In A Year from Monday: New Lectures and Writings, 120-132. Middletown: Wesleyan University Press, 1967.

—. "Diary: How To Improve the World (You Will Only Make Matters Worse) Continued 1970-71." In M: Writings, '67-'72, 96-116. Middletown: Wesleyan University Press, 1973.

- "For More New Sounds." In John Cage: An Anthology, ed. Richard Kostelanetz, 64-66. New York: Praeger, 1970; reprint, New York: Da Capo, 1991. 
—. "The East in the West." In John Cage: Writer, ed. Richard Kostelanetz, 21-25. New York: Limelight Editions, 1993.

Cage, John and Joan Retallack. Musicage: Cage Muses on Words, Art, Music. John Cage in Conversation with Joan Retallack. Ed. Joan Retallack. Middletown: Wesleyan University Press, 1996.

Feldman, Morton and Peter Gena. "H. C. E. (Here Comes Everybody): Morton Feldman in Conversation with Peter Gena." In A John Cage Reader: in Celebration of his $70^{\text {th }}$ Birthday, compiled and edited by Peter Gena and Jonathan Brent, with supplementary editing by Don Gillespie, 51-73. New York: C. F. Peters, 1982.

Haskins, Rob. “Toward a Critical Description of John Cage's Compositions.” Paper presented at the American Musicological Society St. Lawrence Chapter Meeting, Geneseo, New York, April 2002. Abstract from http://robhaskins.net/writings/AMS2002abs.htm.

—_. “An Anarchic Society of Sounds': The Number Pieces of John Cage.” Ph. D. diss., Eastman School of Music, University of Rochester, in progress.

Kostelanetz, Richard, ed. Conversing With Cage. New York: Limelight Editions, 1994.

Nyman, Michael. Experimental Music: Cage and Beyond. New York: Schirmer Books, 1974. 2nd ed, Cambridge: Cambridge University Press, 1999.

Pritchett, James. "Understanding John Cage's Chance Music: An Analytical Approach." In John Cage at Seventy-Five, ed. Richard Fleming and William Duckworth, 249-261. Lewisburg, PA: Bucknell University Press, 1989.

—. The Music of John Cage. Cambridge: Cambridge University Press, 1993.

Taruskin, Richard. "No Ear for Music: The Scary Purity of John Cage." The New Republic Issue 4,078 (March 15, 1993): 26-34. 
Tenney, James. "John Cage and the Theory of Harmony." In Writings about John Cage, ed. Richard Kostelanetz, 136-161. Ann Arbor: University of Michigan Press, 1993.

Visscher, Eric de. "John Cage and the Idea of Harmony." Musicworks 52 (Spring 1992): $50-57$.

White, Robin. “An Interview with John Cage at Crown Point Press." View 1, no. 1 (April 1978): 1-16. 